\title{
A LINGUISTIC AND CULTURAL ANALYSIS OF PUN EXPRESSIONS IN JOURNALISTIC ARTICLES IN JORDAN
}

\author{
Yousef Bader \\ Department of English, Yarmouk University, Irbid, Jordan
}

\begin{abstract}
This study is a linguistic and cultural analysis of some pun expressions published recently in two Jordanian daily newspapers in Arabic. The study responds to calls by Delabatista (1997) and Ritchie (2004) to carry out studies on pun that deal with analysis of its practical uses rather dwell on categorization issues and theoretical backgrounds. The survey finds numerous cases of wordplay in these articles, some of which fall under the category of humor, but many, contrary to what was stated before, cannot be categorized under humor because they refer to recent bloody infighting in the Arab World, especially Syria, and they actually call for tears rather than laughter. Types of word play used include the homographic, homonymic, onomastic, and other types discussed in the literature. The new thing in this study is the case of playing on similarities between two words in taw different languages like Arabic and English to produce a respectable pun.
\end{abstract}

Keywords: Journalistic articles, Jordan

\section{Introduction \\ Definition of Humor and Pun}

Pun is a form of word play usually defined as a "deliberate communicative strategy, or the result thereof, used with a specific semantic or pragmatic effect in mind." (Delabatista, 1997:2). Word play itself is the general name for various textual strategies in which authors exploit the structure of a language to bring about two similar forms with similar meanings (Delabatista, 1996). The last author bases his definition on Adison (1982), who maintains that pun relies on the use of two words that agree in sound (homophones or homonyms) but differ in meaning (polysemes). Similarly, The Free Wikipedia Encyclopedia defines pun, also called paronomasia, as a form of word play which suggests two or more meanings of words or of similar-sounding words, for an intended humorous or rhetorical effect.

Merriam-Webster Dictionary puts it simply as "the humorous use of a word in a way that suggests two interpretations."

For his part, Partington(2009) defines pun in a more phonetic way as "the bisociative play between two sound sequences." (p. 1794). He adds that "the relationship between the different meanings of the two word sequences...will affect its quality, its success or failure." (Ibid.)

Arab authors agree with the above definitions of pun, called tawriyah in Arabic. For example, Al-Hamawi (837 A.H.) states that it consists in using one word with two meanings, one denotational and the other metaphorical. The first is the close meaning and the second is remote. Usually, the speaker or the writer aims at the remote meaning. Similarly, Al-Muraghi (2000:338) focuses on what he calls the "near" and "far" meanings of one single word used for pun.

Scholars like Leech (1969:209), Newmark (1988) and Delabatista (1997) emphasize the homonymous and polysemous nature of words used in pun or word play. They mention the homonymous (different words having identical forms) nature of a word like bank, as in the bank of the river and the bank for money storing, and the polysemic (one word having 
different but related senses) characteristic of another word like foot, as in the foot of the man, the foot of the mountain and the foot-long snake.

Pun is common in literary texts, cinema, and television comedy shows. It also pervades many journalistic articles these days. These so-called ironic or sarcastic columns tackle people's and governments' daily problems in a humorous way, attracting readers and making them fully aware of these problems. Nelson (1978:264) considers irony, satire and pun as varieties of humor found a lot in magazines and newspapers. Rosenthal (quoted in Shunnaq 1996:102) claims that the humor of pun and other verbal jokes derives from the fact that humans express their ideas and feelings through circumscribed and logical elements. Any deviation from these elements, it is added, is felt as a release from conventional restrictions and is, therefore, humorous.

Pun is also used in advertisements to attract attention and make people dwell on the topic (Djafavora, 2008) and in fables which often tolerate more than one meaning (Tragesser and Lippman, 2005). Puns is equally found in the Bible, in orthography (the case of Japanese Kyoka), and in film titles.

In "Pun for the Ages" (The New York Times, March 28, 2008), Joseph Tartakovsky mentions different meanings of pun according to different poets, writers and critics. For example, pun for John Dryden is "the lowest and most groveling kind of wit: For Ambrose Bierce, however, it is "a form of wit to which wise men stoop and fools aspire."

Nordquist (2013) indicates that puns show the arbitrary nature of language - the same sounds can mean such radically different things. "Punning can also be viewed as a test of one's power over other participants in the communicative act." (Delabatista, 1996:140).

"Wordplay can be considered as a strategy of verbal interaction which aims to test our ingenuity both for ourselves and against the cognitive skills of our interlocutors, which may either confirm our superiority over the addressee, or join the speaker and the addressee in a bond of equal power and solidarity." (Op. cit.:152)

Many puns are based on either homonymy (i.e. two different words have an identical form) or polysemy (i.e. a word has different but related senses), and what is at a certain point in time understood as a single polysemous word may well be the result of the merger of two distinct words which happened to have similar forms. Conversely, two meanings of a single polysemous word may get dissociated to the point of breaking up the sense of word identity and growing apart into separate words. For example, 'metal' and 'mettle' are in modern English felt to be two unrelated words but in Elizabethan English there was one word with uncertain spelling having several senses including "metal, substance,and temperament/spirit', between which existed a logical connection (Delabatista, 1994:5)

The study of word pun takes one to the heart of communication, hovering and oscillating, as the pun does, between meaning and form, intention and understanding, between semantics and pragmatics, between langue and parole, between rhetorical control and inept purposeless expression, and cutting across virtually all genre or text type distinctions. (Op. cit.: 9)

Puns never came close to attracting the amount of professional interest to which they may stake a claim. The specialists of language and the acknowledged judges of taste have all stored it away in categories such as 'mannerism', 'poetic licence', 'light verse', and the like, meaning that they marginalize it and disqualify it although it is worthy serious investigation, but now puns and ambiguities are in the process of becoming more respectable research topics. (Ibid.)

\section{Classification of Pun}

Many scholars (Leech, 1969; Newmark, 1988; Delabatista, 1994 and 1997, to cite just a few) have tried to classify pun into different typologies, but it seems that wordplay is 
difficult to classify. The classification below summarizes the different attempts by different authors, but it remains lacking and sometimes repetitive.

Homophonic pun: this kind uses word pairs which are homophones (sound alike) but are not synonyms. Example is George Calin's statement "Atheism is a non-prophet institution". The word prophet here is used instead of 'profit", which is the usual word used in expressions like non-profit organizations.

Homographic or heteronymic pun; this pun uses words that are spelled the same but have different meanings and sounds. Example is Douglas Adam's line "You can tune a guitar, but you can't tuna fish unless of course you play bass." This line contains two types of pun: first, a homophonic pun shown clearly in the words tune and tuna; second, a homographic pun in the word bass in which there is some kind of ambiguity reached through the identical spelling of 'bass', a string instrument and 'bass', a kind of fish.

Homonymic pun: this kind includes exploitation of words which are both homographs and homophones. Example is Isaac Azimov's statement "Did you hear about the little moron who strained himself while running into the screen door?" The word strained carries the two meaning "gave much effort' and 'filtered'.

Compound pun; includes a statement that contains two or more puns. Example is Richard Whately's complex statement "Why can't a man starve in the Great Desert? Because he can eat the sand which is there, but what brought sandwiches there? Noah sent Ham and his descendants mustered and bred." The pun here is first in the phrase sand which is, which is homophonic with sandwiches, and, second, in the homonymic words Ham (Noah's son) and ham (kind of pig meat), mustered/mustard, and bred/bread.

Recursive pun: here, the second aspect of the pun relies on the understanding of an element in the first aspect. Example is the statement "Infinity is not in finity", which means that infinity is not in the finite range.

Visual pun: the pun aspects are replaced by a picture and this kind is sometimes used in cartoons like "The Far side".

Naming or onomastic wordplay (Kaufmann) fulfills an important role in the scriptures, literary and semi-literary works ranging from Asterix comic strips to Dante and Dickens (e.g. Oliver Twist). (Delabatista, 1997)

Another subtype of puns is idiom-based pun or puns in which idioms are manipulated in such a way as to obtain a playful humorous effect. Such pun involves a conflict between the compositional, literal reading of the idiom and its accepted figurative meaning, such as in the idiom 'to be in the doghouse'. (Delabatista 1994, 15). Veisberg (1996), in Delabatista (ed.), dedicates an article to idiomatic pun in translation, calling on translators to "strive for equivalent effect" (p. 155). The data are taken from Latvian, Russian and German translations of Oscar Wilde and Lewis Carroll. Different techniques are suggested to render a similar effect, such as the use of an equivalent idiom, a loan translation, an extension, an analogue transformation, substitution, compensation, loss of wordplay, and metalingual comment. Priorities of technique choice have to be considered according to individual cases and in light of the constraints under which the translator is operating. (p. 155)

\section{Humor in Pun}

The humor of a pun depends very much on the "expectations shared by the framer of the message and the addressee and on the way the latter is taken by surprise and plunged into something entirely different from what s/he has been prepared for" (Delabatista, 1996:138). "Punning should also be considered in relation to another important aspect of human nature, namely our own sense of humour and our desire to produce a humorous effect on the people we communicate with." (p.139) 
Sinclair (2004) states that certain hearers/readers have certain predictions or expectations about how speakers/writers employ language organization principles. Wordplay upsets or exploits these organizational expectations, by relexicalization and rewording. For his part, Hoey (2005) provides a lexical-grammatical framework which sheds light on precisely what the linguistic expectations of hearers/readers are and how they come about in the first place.

Puns or wordplays are based commonly on a "confrontation or clash of two meanings" (Delabatista, 1996:138). One should notice too that puns "result not only from the confrontation of two (or more) different meanings of an identical or similar string of letters or sounds, but also from the clash between two (or more) domains of human knowledge and experience." (Ibid.) In this sense, punning is "a perfect illustration of the close ties between language and thought." (p.152)

The wordplay comic effect strength is determined by showing the distance between the domains of human knowledge and experiences and the way they are connected (Ibid.).

"Punning is possible in any language in so far as it seems to be universal feature of language to have words with more than one meaning (polysemy), different words with the same spelling or pronunciation (homographs and homophones) and words which are synonyms or near synonyms while having different pragmatic meanings and evoking different associations." (Delabatista 1996:138-9)

"Wordplay is inherently linked with the asymmetrical relationship between language and the extralinguistic world, which...is geared to the optimum use of our information processing system." (p.139). It is also dependent on the asymmetry between the more or less limited number of language signs and the much greater number of entities, events, and relationships we experience and try to describe by means of language." (p. 152)

\section{Studies on Pun}

Of all forms of humor, plays on words and puns have received the bulk of attention in linguistic studies. They are the most obviously dependent on a form of wording, and therefore many authors have felt them to be the only kind of humor to constitute a proper object of linguistic studies (Partington, 2009). Attardo (1994:27) indicates that "between playing with an idea or a situation and playing on words, puns are felt to fall squarely into the second category." Partington (Op.cit.) claims, however, that many puns play with ideas as well as words and offers several examples from British newspapers headlines to illustrate his point.

Attardo (1994) indicates that past studies on pun dwelt mostly on "taxonomic" approaches and avoided real "explanatory patterns". In other words, linguistics, as he claims, has tended to give lists of different kinds of puns but has done relatively little to explain how they function in real-life discourse. Ritchie (2004) reflects a similar critical opinion of past research in this area and suggests practical or circumstantial problems in the study of naturally occurring wordplay. Hence, there is an urgent need to study and analyze naturally occurring wordplay and puns, and this is what the present paper intends to do in regard to some newspaper articles in Jordan.

Studies on pun, especially from a literary and translational points of view (e.g. Newmark, 1988; Al-Shamali, 1992; Delabatista, 1997; Girard, 2001; Al-Hafiz, 2002; AlHomoud, 2007; Sayaheen, 2009; and Al-Shra'ah, 2010) are widespread. However, specifically linguistic and cultural works dealing with pun are still few in Arabic, especially with regard to journalistic texts. The use of pun, sarcasm, and irony has been expanding in journalism recently due to the freedom given to the media in the last decade in the Arab World and especially following what is called the "Arab Spring", which began in late 2010 and continued throughout 2011. In Jordan, daily articles by authors like Yousef Ghishan , Kamel Nusairat and Tal'at Shana'ah from Ad-Dustour newspaper and Ahmad Al-Zoubi, Abdel-Hadi Raji AlMajali and others from Al-Rai are most noticeable for their richness in pun expressions and 
sarcasm. Al-Zoubi's and Nusairat's word play were the subject of one MA thesis for each at Yarmouk University but from a translational perspective only. In the proposed study, recent articles by these columnists and a few others will be scrutinized for word play and pun and analyzed from linguistic and cultural perspectives. Many of the wordplay in these articles are derived from local culture and society. Some of it, however, concerns regional and even international politics, as will be seen below.

\section{Pun in Jordanian Newspaper articles}

Newspaper articles or columns tackle the daily life issues and events that people face at the local, regional and international levels. Some of these articles are characterized by their ironic or sarcastic nature. Others criticize events or habits in a humorous way, to attract readers' attention and to make them focus more on the issues under consideration. When talking about humor in newspaper articles, Nelson (1978) classifies irony, satire and pun under humor. Thus, one usually studies pun within the scope of humor. Rosenthal (cited in Shunnaq 1996:102) states that the humor of pun and other forms of verbal jokes stems from the fact that human language moves in narrowly circumscribed and logical channels and any deviation from these channels is felt as a release from conventions and is, therefore, humorous. As will be seen in the examples discussed below, however, not all puns are humorous or motivate laughter, since some of them, having to do with current political or military turmoil in the Middle East, naturally generate a serious or a sad stance from regional (Arab) readers.

In what follows, several examples of wordplay selected from a large corpus of data collected over a period of two months (June-August 2013) are presented and analyzed from a linguistic and cultural perspective. The first two examples, however, are taken from AlShra'ah (2010), who discussed them in his MA thesis from a translational point of view, and go back to a period before 2010. They are analyzed here from a linguistic and cultural viewpoint.

The first example is from one of Nusairat's articles, which is critical of local officials' carelessness and lack of responsibility:

-?al-mas?uluuna na?imuu ?al-'aSr (lit. the officials are sleeping the mid-afternoon).

Stopping work and taking a nap or a siesta in the afternoon is a common practice in Jordan and most Arab and Mediterranean countries. Nusairat refers to this (cultural) practice in the above excerpt to create a wonderful pun. The pun is in the polysemy of the last word (?al-'aSr), which carries at least two meanings: mid-afternoon and a period of time including the present. Hence, the sentence can be paraphrased into two different meanings as follows: the officials are taking a mid-afternoon nap (literal, maybe real for these officials but unintended), and the officials are not aware of or are indifferent about what is happening at the present period of time (remote but intended). Nusairat in this humorous pun is critical of Jordanian officials who do not seem to be up to the events taking place inside and outside Jordan because they are like "sleeping".

The second example is also from Nusairat's articles and illustrates the helplessness of the Jordanian people in its remote meaning:

-laa xayaara ladayna (lit. we have no cucumbers/choice)

This article was written when the prices of cucumbers reached three years ago unprecedented high levels and the vegetable became out of the reach of most Jordanians. Needless to say, cucumbers are an important commodity for all Jordanians and are consumed almost daily by most -if not all- of them either raw or in salads. The pun here is in the word xayaar, which actually has two meanings: cucumbers (near but actually unintended, although the author uses the occasion to complain also about the lack of cucumbers in Jordanian houses due to exorbitant prices of the vegetable) and choice (remote but intended). In fact, the sarcastic columnist seizes the opportunity of the exorbitant prices of cucumbers to lament the 
situation of the Jordanians who have no 'choice', according to him, in the administration of their various (daily or even political, as can be understood by educated local people) affairs.

The following example is from Tal'at Shana'ah's daily columns in Ad-dustour newspaper and illustrates the examples of onomastic or naming puns:

-Ru'yaa fii ramadaan (lit. vision in Ramadan)

The above expression is in fact the title of the article and makes one believe at first reading that the author is going to talk about a vision he had in the Holy month of fasting and special devotion for Muslims (the month of Ramadan). However, when one reads through, he discovers that Shana'ah is actually talking about a local TV channel called "Ru'yaa" and is praising the variety of its religious and comic entertaining programs during the month of Ramadan as opposed to the non-entertaining programs on the national Jordan television. The author is playing on the actual word (ru'yaa 'vision') and the name of the TV channel to underscore the fact that the relatively recent TV channel (Ru'yaa) had a really successful ru'yaa (vision) in Ramadan by attracting more viewers than other, including the longestablished national television, channels. In retrospect, the author is ridiculing or criticizing the national channel's inability to offer programs that attract viewers.

This example also illustrates onomastic or naming pun. It is taken from one of Ahmad Hasan Al-Zoubi's articles in Al-Rai newspaper, which was published July 22, 2013. In the column, the author talks about a once successful local daily newspaper called "Al-'arab alyawm" (lit. The Arabs Today), which decided lately to close down due to mismanagement and other problems. Al-Zoubi laments the fate of the newspaper, which, he says, he used to cherish so much. Then he creates a pun to lament not only the newspaper's fate but also that of the Arabs in general:

-sa?altuh: "shloon il-'arab ilyoom?", wallah ya xaali ?ahmal min 'arab imbaariH (I asked him: How is/are the Arabs t/Today? I swear, Uncle, it is/they are worse than the Arabs of yesterday (the past)).

The author plays on the words ?al-'arab ?al-yawm by switching to Colloquial Jordanian pronunciation (il-'arab il-yoom) of the standard Arabic expression without any change in the written form; the colloquial variety is shown by the word shloon 'how', only used in the spoken form of Arabic. The expression carries two meanings: the first is near (because the topic is about the daily newspaper) but unintended and asks about the situation of the newspaper (How is the Arabs Today (newspaper)?); the second is remote (but intended) and asks about the situation of the Arabs themselves as a nation (How are the Arabs today?). Notice that is and are of the verb TO BE are not required in Arabic and the small and capital initial for the word today in the English translation show the two meanings of the pun. In fact, Al-Zoubi uses this wonderful wordplay to compare the lamentable situation of the oncethriving newspaper with that of the Arab countries today, with in-fighting and killing almost everywhere following the advent of the so-called "Arab Spring" in the year 2011 and after.

This example is from one of Shana'ah's daily columns in Ad-dustour. In it, he describes an invitation to iftaar ('breakfast', or the first meal of the day served following sunset during the Holy month of Ramadan) by Zain (local and regional mobile phone company). The invitees were a mix of officials, ambassadors, journalists, and others and there was an atmosphere of coldness and unsociability during the meal. But when the time came to smoke the argilah (waterpipe), a common practice by all classes of Jordanians these days, the situation changed, and Shana'ah writes:

-wa jaa'at ?al-argiilah kamutanaffas wakulluhah ?anfaas wa-Tayyaba ?allaahu ?al-?anfaaas (lit. and the argilah came as an outlet; all took breaths, and may God make breaths/souls good) The author plays here on the double meaning of the second use of the word ?anfaas, which carries two meanings: the first is near and probably unintended; it is breaths (to refer to smoke breaths taken through the waterpipe or argilah, which usually make people's breath less repellent and more tolerable as the tobacco for the argilah carries different pleasant flavors). 
This is the meaning that can be logically inferred from the context of talking about waterpipe smoking. The second meaning is remote but is probably intended by the author: May God make people's souls or spirits really good, which is a logical and understood invocation in the month of Ramadan, the fasting of which is intended to cleanse souls.

The sixth example is taken from one of Al-Zoubi's articles in Al-Rai Daily. In it, the author talks about Syrian refugees of the recent internal war (2011-2013 and still going on until the writing of this paper in the first months of 2014) on the occasion of the Refugee day on June 20 of each year. In emotional words, the persona or speaker (a refugee) addresses his country saying:

-?atastaTii'a ?an tuharrib lii qiT'ata laylin min baladi lam tuHriquha qaTHiifah aww tumazziquha raSaaSah....limaaTHa, ?uriidu ?an ?atakaffana biha litakuuna "?alkulaaSah/kalaaSah" (lit. Can you smuggle for me a piece of night from my country, which no shell could burn nor a bullet tear... Why? I want to wear it as a shroud to be my end/salvation).

The pun is in the last word which can, according to Arabic orthography which does not mark short vowels, be read into two different ways: kulaaSah (end/conclusion, which might be the near or unintended meaning) and kalaaSah (salvation), which may be the far or intended meaning. In this case, the Arabic script, which does not usually indicate short vowels, allows for this kind of pun (orthographic, as mentioned in the literature). However, in this specific example, it is difficult to say which meaning is intended or unintended and it could be assumed that both meanings were intended by the author, given the sad fate of Syrian refugees these days. If you assume that the refugee (speaker or persona) wished death (especially when talking about dead people's shrouds and the sad situation of the refugees), then the first meaning (end) is intended. But if we assume that the refugee wanted salvation (which is why he has become a refugee), then the second meaning (salvation) is intended. In sum, Arabic orthography and the unclear intended meaning of this pun have made of this wordplay an especially noticeable one, which is an example of a non-humorous wordplay as it refers to the sad situation of the Syrian refugees.

The pun in this example is also from Al-Zoubi of AL-Rai newspaper, who criticizes producers and television channels for the great quantity of 'drama" or shows designed to be aired during the Holy month of Ramadan. The author writes:

-hall naHnuu bi-Haajah ?ila kull haaTHa al-kamm min ?al-draama fi'lan?... siyyama wa-?anna Hayaatana kullaha draama...siyaasatuna draama...?iqtiSaaduna drama...riyaaDatuna draama....Hayaatuna ?al-yawmiyyah ?al-'aadiyyah draama ?ayDan (Do we really need this huge amount of drama?... Especially that our whole life is a drama...our policies are a drama... our economy is a drama... our sports are a drama...our daily routine life is a drama too).

The author uses the word drama into two different meanings: the near but unintended (TV shows depicting complicated stories in real life) and a remote but intended one (tragic or tragedy) when he talks about our whole life, (government) policies, our economy, sports, and daily life. In fact, he sounds pessimistic and actually "dramatizes" the situation in Jordan by deploring the tragic and sad nature of almost everything in the citizen's life. Needless to say, the Arabic word draama carries almost the same meanings as its English equivalent, both of which come from the same Latin or Greek origin (Webster's Online Dictionary)

This example is also taken from the same article by Al-Zoubi. In it, he talks about the 'remote control' in the hands of the United States of America:

-?al-rimoot bi-yadd ?al-wilaayaat ?al-muttaHiddah ?al-amriikiyyah, taTlub ?ash-shashah mata tashaa? wa-kayfa-ma tashaa? litaj'ala ?al-'aalam yutaabi' maa turiiduhu hiya...wa-'alaa mazaajiha(lit. the remote (control) is in the hands of the United States of America; it requests the screen whenever and however it wants to make the world watch what it really wants, according to its whims and wishes) 
The word rimoot carries at least two meanings: the near but unintended and less important (the remote control for a televison set); the second meaning is the one which is remote but intended, i.e. the USA controls and directs what goes on in the world including dramas and tragedies. Stating it in a skillful way, the author uses this pun, in fact, to criticize the USA for causing the world to go through all this drama (tragedies). From the context, one can understand that the author refers especially to the current infighting in Iraq and Syria.

This example is also from the same article. Here, the pun is in the use of the word 'musallsal' (TV series):

-bil-munaasabah ba'D maa tushaahidunahu min mawaaqif ?umamiyyah huna ?aww hunaak laa ta'duu ?an takuuna "di'aayaat" wa "fawaaSil ?i'laamiyyah" bayna musallsalayni mushta'ilayni biddammi wa-nnaar (lit. by the way, some of what you see regarding international positions are only "commercials" or "media breaks" between two series (shows) burning with blood and fire).

The author seems here to be talking about television series full of killings and tragedies (near but unintended meaning). However, he is in fact talking about real episodes of killing and violence in the Arab world, especially with reference to the Syrian scene, where international or Arab mediation is compared to commercial or information breaks between bloody episodes of violence.

This example is taken from Nusairat of Ad-dustour and talks about the persona or author's political affiliation:

-HuTT raasak been ir-ruus wHaTTeet raasii fi'lan been ir-ruus waSirtu yasaariyyan falaa irruus ?i'tarafuu bi ?illa ruus ilbaSal.... waba'da ?an Dayya't ir-ruus wuDi'at 'alayya nuqTah sawdaa? min ?al-amriikaan (lit. Put your head among other heads, and in fact I DID put my head among the heads (the Russians) and I became a leftist. Not even the (heads) Russians recognized me, except for the onion heads.... And after I lost the heads (Russians) I got a black mark from the Americans)

The author in this text plays on the many meanings of the Arabic word ruus, which carries at least three meanings in this text: the first two meanings are close but unintended (human heads and onion heads) and the third is remote but intended (the Russians). The author, I believe, wants to indicate that counting on the Russians will make the person who does so lose both the Russians' (who will not help him) and the Americans' support. Indirectly, the author is probably referring to the case of any regime head who counts a lot on Russian support. It is worth indicating here that the first four words in the excerpt represent the first part of a common colloquial saying in Jordanian which reads: HuTT raasak been irruus wguul ya-gaTTaa' ir-ruus (put your head among other heads and say 'go ahead, head cutter'). This is said when it is impossible for one person to avoid a collective disaster and it represents a call to him to accept his as well as other people's fate. The reference to onion heads is not unclear here unless it is mentioned for the sake of humor only. .

This example is also taken from Nusairat who says:

-dimuqraaTiyyatuna Tiflun xadaaj... mish ma'quul ?ish-sha'b kulluh ?al?aan yumaaris ?alriDaa'ah... biddi ?anfaTim... mishaan ?allah Hadaa yifTimnii (Our democracy is a premature child (needing an incubator)... It is impossible that the whole people is now being breastfed... I want to get weaned... For God's sake, may somebody wean me!)

This quotation carries two interrelated wordplays at least. The first concerns the word riDaa'ah (breastfeeding) which carries the literal near meaning (actual breasfeeding) and the remote and figurative but intended meaning (the people being treated like babies by government officials). This latter meaning criticizes the government for not treating people like adults who can democratically elect their own representatives and officials. The second wordplay is in the word ?anfaTim (get weaned) which carries the literal but probably unintended meaning (to get actually weaned from breastfeeding) and the figurative but 
intended sense (to become and be treated like an adult). The author here calls on the government to treat its people like adults capable of running a real democracy.

The two examples here are actually wordplays on ideas in the sense of Partington (2009). The first one is taken from Nusairat and reads:

-bibsi Hajim 'ashaa?iri (tribal size Pepsi (bottle))

The author is ridiculing here the exorbitant spending on banquets in Jordan and talks about the need for a Pepsi bottle that would be enough for the whole tribe (thousands of people), which is of course impossible, but the idea is presented in such a way as to play on the idea of jumbo or giant banquets offered by certain rich tribal people in Jordan.

In the second example, Nusairat refers to the "goodness" and malleability of the Jordanian people, saying:

-?al-muwaaTin ?al-urdunii 'ajiinah Tayyibah.... yastaTii'u ?al-Mas?uuluuna ?an yushakkiluuhu kaifa shaa?uu (the Jordanian citizen is a good dough... The officials can shape him whatever way they like)

The wordplay on the two meanings of the word dough is clear here: it compares between the original meaning of dough "mixed flour and water" and its other figurative meaning "soft substance" to emphasize the flexibility and malleability of the Jordanian citizen who can be manipulated by government officials to accept any (economic) decision they take.

The following two examples play on the homographic nature of near-puns (Delabatista, 1997). In the first example, the author Ramzi Al-Ghazwi from Ad-Dustour criticizes the General Secondary School Examination or Al-Tawjihi which is held every year in Jordan for high school seniors, saying that it causes so much fear among students and their families and sometimes leads to painful tragedies:

-foobia (xawf) ?al-tawjiihi or ?al-tawjii'i (phobia or fear from al-tawjihi or the pain-causer).

The author here replaces the letter $h$ with the letter ' to underscore the difficulties and pain resulting from holding the yearly examination, although it is a well-established one. Although the exam is required for university admission, the author thinks it is no more necessary.

The second example is taken from Yousef Ghishan from Ad-Dustour too. In it, he makes fun of a statement by a Jordanian official that Jordan will become a nuclear energy exporter by the year 2030. He uses a similar technique as the one used by Al-Ghazwi, i.e. replacing one letter with another:

-sanuSbiHu ?a'Daa? fii munaZZamit OTEC (munZZamit ?ad-duwal ?al-muSaddirah liTTaqah) (We will become members in OEEC (Organization of Energy Exporting Countries)

It is clear how the author plays here on the words OPEC (Organization of Petroleum Exporting Countries) and OTEC (in Arabic) and OEEC (for English translation) to ridicule the Jordanian official's statement, given the fact that Jordan is still in the planning stage of building a nuclear reactor.

This example is taken from Nusairat and says:

-La'alli min ?alqalaa?il fii ?al-Urdun ?al-lathiina tamakkanu min ?al-laff 'ala ?an-naas fii ramadaan (I may be one of the few people in Jordan who have been able to go around to/ fool people in Ramadan)

The author plays here on the double meaning of the word ?al-laff: the near and common but untended meaning : go around to see people, and the remote but intended (fool/deceive, especially regarding commodity prices). The author is referring here to a common local practice where some merchants exploit the desire of people to shop in the Holy month of Ramadan to raise unlawfully the prices of things, counting on people's goodness to take any price.

This example is taken from one of Ibrahim Abdel-Majeed Al-Qaisi articles written towards the end of June 2013 in Ad-dustour on the occasion of the G8 Summit held in 
Northern Ireland, during which a Western official called on the Syrian regime and the Opposition to destroy Al-Qaida:

-yajib 'ala ?an-niZaam ?al-suurii wal-mu'aaraDah ?al-iltizaam bitaddmiir kul ?almunaZZamaat ?al-murtabiTah bil-qaa'idah walam yuuDIH ?akthar 'an ?al-qaa'idah walaakinani ?as-taTii'u ?al-qawl ?anaha laysat qa'idat arxamiidis 'an Hajim ?al-saa?il ?almuzaaH, ?allati yumkin tawZiifuha min ajli fahmin ?awsa' li'amaliyyat ?al-nuzuH ?alsuurii ba'da Huluul ?al-qawa'id makan ?ash-sha'b ?as-suurii fii ba'D ?il-mudun walquraa wal?ariyaaf (lit. The Syrian regime and opposition must commit themselves to destroy all the organizations linked to Al-Qaida. He did not make it more clear about Al-Qaida, but I can say that it is not Archimedes' Law about the volume of displaced liquid, which can be used to better understand the Syrian "displacement" after different Al-Qaidas took the place of the Syrian people in some cities, villages and rural communities)

Al-Qaisai is here ridiculing the feasibility of destroying Al-Qaida (the Jihadist Organization opposing the West and fighting against the Regime in Syria) by both the Regime and the Opposition by playing on the different meanings of the Arabic word ?al-qaa'idah: first, the near well-known meaning (The Jihadist Organization) and the second , remote but intended (law or laws governing natural things and people's lives). The author doubts that this destruction is possible because "many al-qaidas" are there in Syria and these took the place of the Syrian people who fled their towns and villages to other places. The reference to Archimedes' Law here is intended to show yet another meaning of the word ?al-qaa'idah and is used to add humor to the story.

This example also plays on the homography of actually two different words from different language sources. It is taken from one of Shana'ah's articles published after Eid il-fitr (End of fasting) - August 2013. In it, the author talks about the best and worst shows he saw during the Holy month of Ramadan that preceded Eid il-fitr:

-?aswaa? faqarah fii ?as-saa'ah wannisf koomiidia faqarat raania shoo...'alaa shuu? (The worst part of the one-hour-and-a-half comedy was The Rania Show...For what?)

Here, the English word 'show", also used in Arabic with the same pronunciation, and the colloquial Arabic word 'shuu" (what) are spelled the same in the Arabic script and the author uses this similarity to express his dissatisfaction with the Rania Show broadcast on Ru?ya Televison during Ramadan. He actually states that this Rania Show cannot be really called a show by asking the question ?alaa shuu 'for what?'.

This last example has been used by several authors to ridicule statements by several Israeli leaders that Israel is ready for peace with the Arabs:

-?israa?eel musta'iddah lis-salaam ma' il-'arab (Israel is ready for peace with/to greet the Arabs)

The Arabic word salaam actually carries two meanings: the first is near but unintended (peace) and the second is remote but intended (greeting). The various authors here want to stress that the Israeli leaders do not really want peace with the Arabs (because if they really did, they would have withdrawn from occupied Arab territories) but only intend to say hello or shake hands with the Arabs in meetings and peace conferences.

\section{Conclusion}

This paper has dealt with the issue of analyzing wordplay or pun in actual use in writing. It has chosen the field of columns by some satirical authors in two locally wellknown Jordanian newspapers. The study thereby responds to calls by well-known authorities in the field of pun like Delabatista (1996 and 1997), Ritchie (2004), and Partington (2009) who advocated practical works on wordplay as a step forward from mere theoretical works. Data collection has revealed a large corpus of data in which pun is utilized; only seventeen examples have been chosen for analysis and discussion due to their relevance to the current local (Jordanian) and regional (Mid-eastern) situations. Different types of pun, most of which 
are based on the concept of polysemy, have been found to exist in Jordanian journalistic texts, especially the homographic, homonymic and onomastic kinds. In addition, the study has uncovered numerous cases of wordplay on phonetically similar words in two different languages, namely Arabic and English, which could create a wonderful pun. Unlike previous statements that pun always falls under humor, the present study has found out that pun is not always designed for happy laughter. Indeed, some cases of wordplay discussed in the paper call for tears and agony rather than laughter because they deal with current infighting in some Arab countries, especially Syria.

It is hoped that the present study will open the door for more studies on pun in other Jordanian and Arab newspapers, especially those affiliated with local parties and groups and some electronic ones. Such practical studies will undoubtedly shed more light on the widespread use and functions of wordplay to determine its universality and practical value.

\section{Note}

The following phonetic symbols are used in the transliteration of Arabic forms:

\section{Consonants}

\begin{tabular}{|c|c|c|}
\hline & Alphabe & Description \\
\hline$\therefore$ & ? & Glottal stop \\
\hline ب & $\mathrm{b}$ & Voiced bilabial stop \\
\hline$ت$ & $\mathrm{t}$ & Voiceless dento-alveolar stop \\
\hline 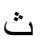 & th & Voiceless inter-dental fricative \\
\hline ج & $\mathrm{j}$ & Voiced alveopalatal affricate \\
\hline$\tau$ & $\mathrm{H}$ & Voiceless pharyngeal fricative \\
\hline$\dot{\tau}$ & $\mathrm{x}$ & Voiceless uvular fricative \\
\hline د & $\mathrm{d}$ & Voiced dento-alveolar stop \\
\hline ذ & $\mathrm{TH}$ & Voiced alveolar fricative \\
\hline J & $r$ & Voiced alveo-palatal trill \\
\hline j & $\mathrm{z}$ & Voiced alveolar fricative \\
\hline س & $\mathrm{s}$ & Voiceless alveolar fricative \\
\hline ش & sh & Voiceless alveopalatal fricative \\
\hline ص & S & Voiceless alveolar emphatic fricative \\
\hline 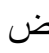 & $\mathrm{D}$ & Voiced alveolar emphatic stop \\
\hline b & $\mathrm{T}$ & Voiceless dento-alveolar emphatic stop \\
\hline ظ & $\mathrm{Z}$ & Voiced alveolar emphatic fricative \\
\hline$\varepsilon$ & 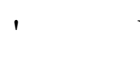 & Voiced pharyngeal fricative \\
\hline$\dot{\varepsilon}$ & gh & Voiced uvular fricative \\
\hline فت & $\mathrm{f}$ & Voiceless labio-dental fricative \\
\hline ق & $\mathrm{q}$ & Voiceless uvular stop \\
\hline ك & $\mathrm{k}$ & Voiceless velar stop \\
\hline 」 & 1 & Voiced alveolar lateral \\
\hline$r$ & $\mathrm{~m}$ & Voiced bilabial nasal \\
\hline ن & $\mathrm{n}$ & Voiced alveolar nasal \\
\hline$a$ & $\mathrm{~h}$ & Voiceless glottal fricative \\
\hline 9 & $\mathrm{~W}$ & Voiced labio-velar glide \\
\hline ي & $\mathrm{y}$ & Voiced palatal glide \\
\hline
\end{tabular}

Vowels:

Short Long

$\begin{array}{llll}\text { a } & \text { Mid low } & \text { aa } & \text { Mid low } \\ \text { i } & \text { High front } & \text { ii } & \text { High front }\end{array}$




\section{References:}

Al-Hafiz, A. 2002. "Problems in Translating English Journalistic Texts into Arabic." International Journal of Translation 14:1,76-103.

Al-Homoud, E. 2007. Translatability of Pun in the Poetry of Ahmad Matar: A Study of his Latafat. MA Thesis, Yarmouk University, Irbid, Jordan.

Attardo, Salvatore. 1994. Linguistic Theories of Humor. New York: Mouton. Al-Shamali, M. 1992. Managing in Translating English Journalistic Texts into Arabic. MA Thesis, Yarmouk University, Irbid, Jordan.

Al-Shra'sh, M. Translatability of Pun in Sarcastic Articles from Arabic into English: A Case Study. MA Thesis, Yarmouk University, Irbid,Jordan.

Delabatista, D. 1994. Focus on the Pun: Wordplay as a Special Problem in Translation Studies. Amsterdam and Atlanta: Rod Opi.

Delabatista, D. 1996. Wordplay and Translation (vol.2). Manchester: St. Jerome Publishing. Delabatista, D. 1997. Traductio: Essays on Punning and Translation.

Manchester: St. Jerome Publishing. Girard, A. 2001. "On the Relative Untranslatability of Puns." Retrieved Febr.26, 2012 from http://www.Multilingual/Webmaster.com.

Hoey, Michael. 2005. Lexical priming: A New Theory of Words and Language. London: Routledge.

Leech, G.N. A linguistic Guide to English Poetry. New York: Longman.

Newmark, P. 1988. A Textbook of Translation. London: Prentice Hall.

Nordquist, Richard. 2013. "Notes on Pun". Retrieved July 7, 2013 from www.About.com Guide.

Oxford Online Dictionary.

Partington, Alan Scott. 2009. "A Linguistic Account of Wordplay: The Lexical grammar of punning." Journal of Pragmatics 41,9:1794-1809.

Preminger, Alex. 1986. The Princeton Handbook of Poetic Terms. Princeton, N.J.: Princeton University Press.

Ritchie, Graeme. 2004. The Linguistic Analysis of Jokes. London: Routledge.

Sayaheen, B. 2009. The Translation of Culture-Specific Ironic Expressions. MA Thesis, Yarmouk University, Irbid, Jordan.

Shunnaq, A. 1996. "Semanticity, Pragmaticity, and Translatibility of Jokes in

North Jordan." International Journal of Translation 8:1-2.

Sinclair, John. 2004. Trust the Text: Language, Corpus and Discourse. London: Routledge. Tartakovsky, J. 2008. "Pun for the Ages." The New York Times (March 8, 2008). Retrieved Jan. 20, 2012. 